\title{
Evaluation of Microfinance indicators in actualizing vision 2030 in the agricultural sector, Kenya
}

\author{
Rose Kerubo Nyanchama Mayianda \\ $\mathrm{PhD}$ Candidate at Kisii University, Kenya.
}

\begin{abstract}
Microfinance institutions play a major role worldwide towards poverty eradication especially amongst the small and micro enterprises. Microfinance has evolved as an economic development approach intended to benefit lowincome women and men. It's a provision of financial services to low-income clients, including the self employed. Financial services generally include savings and credit; however, some microfinance organizations also provide insurance and payment services. In addition to financial intermediation, many MFIs provide social intermediation services, such as group formation, development of self confidence, and training in financial literacy and management capabilities among members of a group. Thus, the definition of microfinance often includes both financial intermediation and social intermediation. Microfinance is not simply banking, it is a development tool. With regard to attainment of Kenya increased value in agriculture, the role of micro-finance cannot be overlooked. There is need to find out the contribution of the MFIs in the attainment of increased value in agriculture. According to the Economic survey report on the attainment of Kenya Increased value in agriculture by 2030, Reasons for lower Growth than the Projected were partly attributed to comparably higher interest rates which later led to crowding out private sector investment. The importance of MFIs in attaining the Kenya Increased value in agriculture comes into play taking into account its accessibility in terms of cost. This study sought to find out microfinance indicators contribution to vision 2030 on increased value in agriculture. A correlation research design was employed in this study. The study targeted 6,134 farmers spread in 47 counties as obtained from 17 Microfinance institutions in the county. The study sampled 362 respondents randomly stratified according to their counties. Primary data was collected using questionnaires. Secondary data was obtained using document analysis. A pilot study was conducted to determine reliability and validity of the research instruments using Cronbach alpha and content validity respectively. Descriptive and inferential statistics were used for the purpose of data analysis. To test the research hypotheses, Pearson correlation and regression were used to measure the general relationship between dependent and independent variables. The findings revealed that microfinance institutions indicators have significant contribution to the increased value in agriculture. Microfinance outreach played significant role in the realization of increased value in agriculture through its depth and breadth. MFI portfolio quality had positive contribution to the realization of increased value in agriculture but the contribution is not significant due presence non-performing loans in some MFIs. Efficiency of MFIs operations had significant contribution to realization of increased value in agriculture as the MFI clients can easily access credit. MFI sustainability had significant positive contribution to the increased value in agriculture. The study recommends the MFIs should reach out to more people as the counties have high levels in poverty index.
\end{abstract}

Key Words: Microfinance Institutions indicators, vision 2030 in the agricultural sector, Kenya

DOI: $10.7176 /$ RJFA/10-4-15

\section{Background Information}

Research suggests that the reach of microfinance differs according to the purpose and deliverers of programs. Nongovernment organizations (NGOs) tend to have a deeper reach, or at least aim to deepen their reach. Private sector organizations and microfinance institutions aligned with mainstream finance providers tend to have a shallower reach, but a greater breadth of reach (Morduch, 2000). In countries such as the United States and the United Kingdom, many people do not have a bank account and are therefore referred to as 'unbanked'. However, in Australia less than 1 per cent of people have no basic financial products (Chant Link, 2004), primarily because the government only pays benefits through bank accounts. However, internationally, microfinance programs have tended to focus on those people who are considered to be moderately poor or those people living just above the poverty line but vulnerable to slipping back below the line. World Bank (2012) notes, that for the past two decades most Asian Tigers have witnessed significant changes that can be traced to MFIs.

The potential benefit from promoting access to formal lending institutions is high in sub Saharan Africa since there are a substantial number of small and micro enterprises. According to calculations from Schneider (2002), the informal economy accounted for 43.2 percent of GNP for sub Saharan Africa in 1999-2000 and 81 percent of those employed in the informal economy in sub Saharan Africa (excluding South Africa) are self-employed (ILO, 2002). Access to financial services is imperative for the development of the informal sector and also helps to mop up 
excess liquidity through savings that can be made available as investment capital for national development (World Bank-Africa Region, 1999). Microfinance as a sector has the potential to reduce poverty by bringing a significant improvement in the lives of the active poor who are largely women (World Bank-Africa Region, 1999).

The data, supported by rigorous statistical evidence in related literature on the use of microcredit around the world, demonstrate that economic gains from microcredit have been more modest than what was once believed. On the other hand, the analysis suggests that the poor save in order to start new businesses and that the introduction of formal products for small savings can be a key financial innovation (Aggarwal, 2012). The importance of MFIs in attaining the economic pillar of the Kenya is to increase value in agriculture by enabling small holder's farmers to access credit. The capital market in Kenya has the potential to contribute substantially towards the country's longterm development goals including a 10 percent economic growth by 2030 . However, Kenya's capital market is still in its infancy stage given that only 29 firms are listed compared to South Africa's 410 and may therefore not fully contribute towards the attainment of Kenya's long term goals. On the other hand relying on commercial banks for economic development funding although locally available, may be expensive.

While a healthy economic growth such as the one envisioned in Kenya Increased value in agriculture of 10 percent is an important basis for economic development, investment is a key factor for economic growth. The World Bank has warned the current growth model in Kenya cannot push growth rates to 10 per cent as per increased value in agriculture dreams. The bank asserts the overall level of savings and investment needs to increase in order to raise the economy's potential growth (World Bank, 2014). Thus a financial system which is accessible by the majority of Kenyans, especially micro-finance, which provides cheap credit to micro-investors, plays an important role in financing economic development.

Although small in volume, the fact that micro-credit is available to a majority of Kenyans has a collective potential to contribute to part of the 10 percent economic growth envisioned in the Kenya Vision 2030. Micro finance institutions are able to achieve this goal through collecting surplus money from savers and depositors who are in the majority, and allocate it to a large number of producers and creators of wealth. All this is done at a very small interest rate and favorable terms offered by MFIs which are affordable to the majority of Kenyan population (Muturi, 2015). Although MFIs have been perceived to increase production of goods and services into the economy, limited studies have demonstrated where and by how much MFIs need to improve their operations to enhance increase in efficiency of MFI supported businesses. This study seeks to identify the actual contributions being made by the MFI to the economic development pillar envisaged in the vision 2030 .

Sharper focus on the MFI sub sector as an important contributor towards Kenya's long term economic goals is justified because of the large majority of the population it covers and in contrast alternative sources of development capital such as the securities exchange may take a while to take root. For example while the primary auction market for government securities remains active; the secondary trading at the Nairobi Securities Exchange (NSE) is still low. The NSE's stock market capitalization to GDP ratio stood at 43 per cent in 2007 compared with South Africa's 266 per cent, Nigeria's 63.8 per cent and, in Asia, Hong Kong's 127.6 per cent and Malaysia's 67.2 per cent (World Bank, 2014).

\section{Kenyan increased value in agricultureon increased value in agriculture}

Agricultural sector is important to the overall economic growth and development in Kenya. The sector contributes about 25 percent of the Gross Domestic Product (GDP) and 75 percent of industrial raw materials. It further accounts for 65 percent of Kenya's total exports, 18 percent and 60 percent of the formal and total employment respectively. In the national development agenda, agriculture is expected to lead the growth and transformation of the economy and maximize the benefits of accelerated growth. Kenya Vision 2030 has identified agriculture as one of the six key economic sectors expected to drive the economy to a projected 10 percent economic growth annually over the next two decades. The sector is therefore central to the achievement of Vision 2030 goals of "a globally competitive and prosperous nation with a high quality of life by 2030 ". During the implementation of the First MTP (2008 - 2012) of Kenya Vision 2030, the sector recorded an average annual growth of 4.3 percent.

Kenya will raise incomes in agriculture, livestock and fisheries even as industrial production and the service sector expand. This will be done by processing and thereby adding value to her products before they reach the market. She will do so in a manner that enables her producers to compete with the best in other parts of the world. This will be accomplished through an innovative and creativity, commercially oriented and modern agriculture, livestock and fisheries sector. These interventions are expected to generate an additional KSh.80-90 billion increase in GDP, mainly through better yields in key crops, increased smallholder specialization in the cash crop 
sector (2-3 crops per plot), utilization of a million hectares of currently uncultivated land, and new cultivation of up to 1.2 million hectares of newly-opened lands (The National Economic and Social Council of Kenya, 2007).

Specific strategies will involve the following: (i) transforming key institutions in agriculture and livestock to promote household and private sector agricultural growth; and (ii) increasing productivity of crops and livestock. Kenya will also introduce new land use policies through: better utilization of high and medium potential lands by her farmers; preparation of new land for cultivation by strategically developing more irrigable areas in arid and semi-arid lands for both crops and livestock; and by improving market access for small holders through better marketing.

Vision 2030 is the country's new development blueprint covering the period 2008 to 2030. It aims to transform Kenya into a newly industrializing, "middle-income country providing a high quality life to all its citizens by the year 2030". The Vision has been developed through an all -inclusive and participatory stakeholder consultative process, involving Kenyans from all parts of the country. It has also benefited from suggestions by some of the leading local and international experts on how the newly industrializing countries around the world have made the leap from poverty to widely-shared prosperity and equity. The Vision is based on three "pillars (MTP, 2012). The pillars are the economic pillar, the social pillar and the political pillar.

The economic pillar aims at providing prosperity to all Kenyans through an economic development programme aimed at achieving a gross domestic product growth rate of $10 \%$ per year over the next 25 years (The National Economic and Social Council of Kenya, 2007). After consultation with experts, stakeholders, policymakers and investors the team settled for six priority sectors that promise to raise Kenya's gross domestic product by $10 \%$ these sectors include tourism, agriculture and livestock, wholesale and retail, trade, manufacturing, finance and business process outsourcing (MTP, 2012).

The main aim of increased value in agriculture includes Economic growth, Equity and poverty reduction, Rehabilitation and expansion of infrastructure, Improving governance and enhanced security. This study focused on the economic pillar which is in line with the objective of economic growth and also the objective of equity and poverty reduction. The economic growth objective underpinning Increased value in agriculture require the rate of growth of the economy to rise from $6.1 \%$ achieved in 2006 to $10 \%$ by $2012 / 2013$ and to sustain thereafter. This growth of economy can be achieved through maintaining a flexible exchange rate system that facilitate economies competitiveness in line with export led private sector, also by encouraging investment and saving which is expected to raise GDP (MTP, 2012). Though according to the World Bank (2014) they have mentioned that Kenyan economy grew at 5.4\% in 2014, 6.0 percent in 2015 and they project a growth rate of 6.6 percent and 7 percent in 2017.This is below the standard set by the Increased value in agriculture which requires $10 \%$ economic growth rate.

Equity and poverty reduction is another objective of the Kenya increased value in agriculture which can also be met by microfinance institutions. This objective is aiming at ensuring that growth is shared among a number of target fiscal intervention, structural reforms and regional development initiative have been implemented to reduce poverty and inequality in Kenya.

The social obligation of MFI is to make financial services available to the poor through outreach programmes. MFI outreach is defined in terms of breadth and depth of financial services advance to their clients. According to Jay (2010) outreach is central in MFIs activities as its outlines its vision in improving lives of its clients. In line with increased value in agriculture, MFIs are vital in advancing credit to the communities which are financially constrained but have feasible, practicable and promising investment business ideas. Increasing MFI outreach results to providing credits to many clients who start various income generating activities while at the same time MFIs enjoy economies of scales translating to MFI growth and sustainability. However, this requires adequate funding to facilitate reaching to communities where poverty is prevalent with aim of improving their socioeconomic status. It's worthwhile to examine the influence of MFI outreach in the realization of vision 2030.

Portfolio is the total available fund hold by MFIs to use as credit products as it reach out to its clients. In order to realize economic and social pillar of vision 2030, MFIs should have sufficient portfolio especially if they are to achieve breadth of outreach. Since loan portfolio is the largest MFIs asset (Nelson, 2011), there is need to protect it against all kind of risk. The measures of how well the MFI is able to protect its portfolio from these risks are known as portfolio quality. Strong portfolio quality makes an MFI to be more resilient especially in time of disasters and this improves their ability to remain sustainable in serving the poor (Muriu, 2011). In examining the contribution of MFI in realization of increased value in agriculture, it's vital to analyses the portfolio quality as it 
is the largest source of risk to MFI whose main aim is to increase depth of outreach through serving the poorest in the community without secured collateral.

MFI efficiency is the optimal combination of inputs such as staff number, staff time and cost of operation with aim of obtaining output such as reaching maximum clients and delivering range of quality services. An MFI which pursue efficiency will afford to use minimum cost to the unit of products and clients. Further, an efficient MFI attract funding decision from both the state and donor and therefore increase their ability to serve the poorer clients. Hartarska, Caudill, \& Gropper (2006), revealed increase in efficiency contribute to decrease in cost of credit to the low income and poor clients thereby making lending more beneficial to socio-economic status of the clients. Further, cost efficient MFIs are able to prevent them from mission drift of crowding out poor clients (Freixas \& Rochet, 2008). Hence, it is essential to assess the efficiency of MFI operations on the realization of increased value in agriculture.

\subsection{Statement of the problem}

Agriculture which is one of economic pillar for vision 2030 contributes more than 60 per cent of the total export earnings and about 45 per cent of government revenue, while providing for most of the country's food requirements. The sector is estimated to have a further indirect contribution of nearly 25 per cent of GDP through linkages with manufacturing, distribution, and other service related sectors. Agriculture influences overall economic performance whereof periods of high economic growth rates have been synonymous with increased agricultural growth. However, there has been reduction of food production locally resulting to skyrocketing food prices, collapse of agro-based processing industries due to lack of raw materials and importation of food stuffs. Further, Kenya's gross domestic product (GDP) growth rate has been ticking along steadily at between $4-5 \%$ over the past five years. At no point has it hit the Vision 2030 target of $10 \%$ despite the huge agricultural potential to drive realization of vision 2030 .

Kenya has high potential in agriculture and livestock coupled with two rain seasons annually and arable land. However, the country has recorded low yield in agriculture and livestock productivity (Adijah et al., 2011). This is because there is low input access and affordability as well as lack of adequate capital to invest in high yielding agricultural production. According to Economic Survey (2015), the county heavily relies on cash crop and food crop industries which are adversely affected by external competitors in the region. This renders majority of residents unemployed and reduces productivity of agricultural farmers.

Despite heavy investments aimed at the Micro-finance sector, the Kenya Government has not articulated the indicators of contributions made by MFI supported businesses towards economic growth especially in the context of the Kenya Vision 2030. Comparative statistics between South East Asian countries and sub Saharan countries show an average loss of 12 and 33 percent respectively in production due to operations of MFIs such as client exit, grace period, terms and conditions, poor loan retention programs and group dynamics (Hardy et al., 2012). This loss in production has consequently led to a loss of between 2- 5 percent in economic growth within Kenya in the agricultural sector, hence the justification of this study.

\subsection{LITERATURE REVIEW}

\subsection{Commercialization and productivity in Agricultural sector}

Agriculture, which is the backbone of Kenya's economy and contributes 15.2 percent of the GDP, employment and livelihood, is marred by numerous challenges. Climate change, use of outdated technology, pest and diseases, soil nutrient deterioration, poor infrastructure are among the issues that prohibit the growth of the industry, hence recommended the commercialization and value addition to boost productivity in the sector (KIPPRA, 2017). Vision 2030 seeks to grow Kenya's economy into middle-income economy by achieving a 10\% GDP growth rate by year. Kenya's 2017 GDP was projected to grow at $5.7 \%$ but below $4 \%$ points required for the country to actualize the $10 \%$ vision 2030 .

\subsubsection{Strategy for Revitalization of Agriculture sector}

As a revision of the Strategy for Revitalizing Agriculture (SRA), the ASDS has incorporated not only the successes but also the lessons learned from the SRA to provide the framework for stimulating, guiding and directing progressive agricultural growth and development in the next 10 years. The document proposes realistic policies and institutional changes that its believed was necessary in contemporary Kenya for creating a vibrant and productive agricultural sector. It expected the strategy to encourage and enhance positive participation among the civil society, individual farmers, farmer organizations and even the private sector. The interventions and reforms proposed in the strategy was based on the need to achieve transparency, accountability, efficiency and effectiveness in performing the duties in the agricultural sector (GOK, 2010). 


\subsection{MFI outreach}

Extending microfinance services to underserved people who have been locked out by formal financial institutions is classified as outreach. Microfinance outreach is vital on the realization of economic growth and development as it extends financial services to unbanked population for the purpose of income generating activities. Outreach is central in microfinance activities because it defines the visions of MFIs in improving lives of its clients especially the poor. Outreach is determined by how far microfinance as a financial institution has gone to reach those who have been denied formal financial services. The availability of financial services acts as a buffer for sudden emergence business risk, seasonal shrimps or events such as flood or a death in the family that can push a poor family into destitution (Chu, 2008).

According to Lafourcade et al. (2005) the two most common aspects of microfinance outreach are depth and breadth. Depth of outreach is the socio-economic level of MFIs client and it represents the poverty of clients been served by a Microfinance institutions. Breadth is the count of clients served by the MFI and the volume of services in offered in term of total saving and outstanding portfolio. The proponent of MFI outreach should have the mechanism and ability to cover remote and poor areas with aim of promoting unemployed population to create and develop various projects for incoming generating (Malkawi \& Atoom, 2011).

The proponents of MFI depth is that the principal aim of MFIs is to serve poor individuals who are omitted from commercial banks credit thus depth is vital for achieving microfinance social objectives of poverty alleviation. Depth of outreach accords the gain from microcredit a given borrower from society stands to benefit as a result using micro credit product and services. Proponents of MFI breadth indicated that MFIs should have large scale coverage so that they have wider audience for loans and other financial services. The breadth would make differences in term of poverty level that can be tracked by loans disbursed, saving volume and active numbers of opened accounts (Navajas, Schreiner, Meyer, \& Gonzalez-Vega, 2000). However, there is paucity of literature on MFI outreach and realization of increased value in agriculture. However, majority of researchers have examined outreach level, outreach and poverty alleviation as well as outreach and performance of MFIs. In relation to the level of outreach, Kavoo (2013) revealed that MFI outreach had significance effect on growth of seven MFIs as shown by increase in number of borrowers and increase in average loan size in Nakuru County. The same findings were obtained by Arodi (2013) where the outreach of 8 MFIs in Nairobi County rose by 12\% between 2008 and 2012. Both studies revealed that there has been increase in outreach of the MFIs, however, their effect on socioeconomic status of the beneficiaries were not indicated. They focused on benefit microfinance derived as a result of increased outreach without considering how the clients benefit from increased outreach. As opined by Kidzuga (2013), the main purpose of MFI outreach is to have both economic and social impact on the livelihood of the borrowers. These two studies left a significant gap which this study filled by assessing the role of MFIs outreach on the realization of Increased value in agriculture.

Bereket and Lalitha (2009) established a strong and positive relationship between breadth of outreach and operation performance of MFIs. Using a sample of 30 MFIs in Kenya, Kidzuga (2013) portrayed that a positive correlation between depth of outreach and performance of MFI. Chemining'wa (2013) established that depth of outreach had significant effect on performance of 8 MFIs in Kenya while breadth of outreach had insignificant effect. In spite of the overwhelming evidence that outreach has positive effect on MFI performance, Noella (2012) using 15 MFIs in Burundi established average loan size, active loan accounts and number of women borrowers did not explain performance of MFI. The findings of these studies contradicted each other though they used same study variables. In addition, there studies was one sided as the relationship between outreach and MFI performance did not factor in what the clients stand to gain or loss as a result of MFI outreach programme.

\subsubsection{Portfolio quality of MFI}

Portfolio indicates to total funds available for the MFI to use as loans to its clients. In meeting it social objective, MFIs are required to hold sufficient portfolio so as to increase it outreach programme and at the same time becoming financial sustainable. Loan portfolios are those loans which have been made by MFIs or bought by clients or are being held by borrowers for repayment. Nelson (2011) asserted that loan portfolio is the largest MFIs asset since the core function of MFIs is to disburse loans funded by NGO, saving and loans from commercial banks. Therefore, portfolio quality is a measure of how well or how best the institution is able to protect this portfolio against all forms of risks so as to effectively advance microcredit to existing clients or new clients. For realization of vision 2030, MFIs need to take care of their loan portfolio since it's presumed by increase in advance of microcredit results in increase of household income.

The worth of MFIs loan portfolio does not depend on loan interest earned but on the likelihood that the principal and interest repayment will be honored (Jasson, 2002). Portfolio quality is a crucial area of MFIs performance 
analysis, since their largest source of risk resides in their loan portfolio. The risks associated with loan portfolio are classified as financial such as credit, liquidity and market risk or non-financial risk such as operational and strategic risks (Al-Azzam et al., 2011). Credit risk which comprises of transaction risk and portfolio risk is the most common type of risk that threatens the operation of MFIs in the realization of increased value in agriculture (Nelson, 2011). Transaction risk is related with an individual borrower transacting with MFI. When a borrower defaults or fails to repay a loan due to business failure or untrustworthy, an MFI suffers transaction risk and this result to reduction in loan portfolio.

Torres (2013) revealed that portfolio quality of MFIs is in downward trend and there was a sharp decline in PAR $>30$ days from $3.0 \%$ to more than $5.0 \%$ between 2009 and 2013 . This resulted to portfolio deterioration affecting the ability of MFIs to increase it outreach and continue sustaining MFI businesses especially in sub Saharan Africa. Lafourcade et al (2006) using data of 163 MFIs in 25 African countries revealed that MFIs have low PAR $>30$ days of $4.0 \%$ as compared to the global which stood at 5.2\%, South Asia 5.1\% East Asia 5.9\% and Latin America 5.6\%. They stated that MFIs facing poor portfolio quality resort to writing off the loans which negatively affects performance of MFIs in meeting its fixed costs.

Studies have revealed that effort to uphold portfolio quality had impact on the performance of MFI supported business and other beneficiaries. In Ghana, Appiah (2011) indicated that loan default affected SMEs financing negatively as borrower suffers the consequence of the opportunity cost of evading the loan and loss of character which hinders him or her from accessing credit from any other MFIs. Likewise, Sarker (2013) revealed that pressure from management to loan officers to collect repayment lead to borrower's loss their household items and livestock leading to panic to those who are beneficiaries. Gwendolyn (2001) and Vogelgesang (2003) revealed that pressure exerted on borrowers to repay the loan result to multiple borrowing from other MFIs, money lenders and family members. The end result is occurrence of over-indebtedness which sometimes make client poorer.

From the reviewed literature, it is evident the MFIs need loan portfolio to effectively achieve the objective of extending microcredit to its clients in particular to agricultural farmers. The ways in which MFIs ensure the quality of portfolio is upheld would have an impact on the client business and investments which in most cases are considered riskier than formal financial institutions. Similarly, the quality of MFI loan portfolio would also influence their effectiveness in meeting their social mission of focusing to unbanked population without drifting. Therefore, this study formulated the second objective of the study with aim of testing whether portfolio quality of MFI has significant role on the realization of increased value in agriculture.

\subsubsection{The efficiency of MFI operations}

Efficiency is how well MFI allocate the input resources such as subsidies, asset and personnel to produce output measured in terms of poverty outreach and loan portfolio (Bassem, 2008). Efficiency of MFI has not been a key indicator of micro finance institutions as compared to commercial banks. This is because they were initially design to deliver loan services to the poor who were excluded from mainstream commercial financial institutions that require collateral for loans products. For the realization of Vision 2010, there is need for MFI to be efficient especially in the management of loan portfolio. They need to allocate input for better production of output that is geared toward the realization of vision 2030.

Nieto et al. (2007) noted that efficient operation of MFIs is paramount to financial sustainability and performance improvement of MFI supported businesses. An efficient MFI is able to allocate its resources better and minimize any wastage which in turns lead to social and financial performance. The level of MFI efficiency can be attributed on allocation of input and at the same time output variables. The input variables include staff, loan officers, and administrative expenses while output variables include number of clients, loan sizes, and number of loans and composition of loan portfolio (Balkenhol, 2007). According to Nghiem et al., (2006), Brau and Woller (2004) and Essential (1999), an efficient microfinance institution, and for that matter, a best practice MFI, is the one that is able to meet both objectives of poverty reduction and financial sustainability requirements.

However, evidence from various empirical studies has shown that there is element of inefficiency in MFIs when compared to other financial institutions and this has affected their operations. Only few hundred MFIs have been found to sufficiently stable while most of them are deemed weak and donor dependent (Littlefield \& Rosenberg, 2004). This has resulted to microfinance reaching small percentage of estimated clients who are considered poor and they are in dire need of financial products. Efficiency of MFIs is critical for its long term sustainability and as such, this empirical study sought to include it effect on the realization of increased value in agriculture. The increase in empirical studies of efficiency of MFI is borne on the nexus microfinance and its social and financial objectives. 
Hassan \& Sanchez (2009) indicated south Asia MFIs are more efficient as compared to Middle In relationship between efficiency and other MFI indicators such as outreach, Hermes et al. (2011), indicated that outreach and efficiency are negatively related. They revealed that MFI with more women borrowers are not more efficient and therefore efficiency can be enhanced if poor client are less in the MFIs clientele profile. In line with achieving Increased value in agriculture, poverty index is key indicator rather than improving economic condition of well of in the society. This study endeavors to investigate the MFI efficiency in realization of economic pillars of vision 2030. However, Kaur (2016) in India did not found any tradeoff between social obligation of MFIs (reaching to women and poorest) and financial efficiency of MFIs. This indicated that efficient MFIs are not able to contribute better in improving economic conditions than the contributions to poverty alleviation made by MFI concentrating on outreach rather than efficiency. The mixed outcome of these studies leave a significant on MFI efficiency and poverty alleviation as enshrined in increased value in agriculture.

The effect of MFIs efficiency is well articulated in microcredit market in Ghana. Amanor (2012) indicated that most of the MFIs in Ghana are below par in terms of their operating efficiency and this affects their productivity negatively. Only $10 \%$ of active and bankable poor are reached by the MFIs. Most of the MFIs are also believed to be on donors' budget and without donor fund they cannot function properly. Further, Amanor (2012) revealed that some MFI officials have redirected loanable funds for client disbursement to financing personal projects. However, Martinez-Gonzalez (2008) indicated that MFIs efficiency put the institutions at crossroad. Most of the MFIs tend to be efficient in order to achieve sustainability and in the process, they fall short of achieving MFI outreach in targeting the people. This implies that the strife to improve MFI efficiency jeopardize the scope of reaching out to the poor. Therefore, wealthy borrowers stand to benefit from increasing efficiency while the welfare of poor borrowers is at risk.

In this study, the researcher was interested in assessing efficiency of MFIs in the achievement of increased value in agriculture. The empirical review revealed that MFIs need to efficient so that they can be financially and operational sustainability and the same time reach out to the poorest of poor. Further, reviewed literatures have indicated mixed outcomes in MFIs efficiency as far as attaining dual objective of social mission through outreach and MFI sustainability is concerned. Some studies have indicated that efficient MFIs tend to crowd out the poor while focusing on the rich client while some have indicated that efficient MFIs tend to provide credit to the poor thus sustaining their livelihood. In the formulation of third hypothesis, the researcher was keen to identify the significant contribution of efficiency of MFI operations on the realization of increased value in agriculture.

\subsection{METHODOLOGY}

\subsection{Research Design}

A research design is the program that guides the investigation of the research in collection, analysis and interpretation of observations made (Nachmias 2005). It is a logical model of proof that allows inferences to be drawn concerning causal effect relations between the variables under investigation. It also defines the domain of generalization to a larger population or to different situation, (Amazon 2008). Research design can also be thought of as the structure of research. It is the glue that holds all of the elements in a research project.

Correlation design was used in order to find the relationships among the different variables of interest. Correlation design was used in this study. Correlation studies may be broadly classified as either relational studies or as prediction studies (Gall et al., 2003; Kothari, 2004). Mugenda and Mugenda (2003) state that Correlational method describes in quantitative terms the degree to which variables are related. Correlational research involves collecting data in order to determine whether and to what degree a relationship exists between two or more quantifiable variables. The degree of relationship is expressed as a correlation coefficient (r).The design is appropriate for determining in quantitative terms the existence of degree of relationship between the peace initiative programmes and achievement of their objectives plus highlighting the underlying challenges facing the peace initiative programmes. The suitability of this design was justified by the fact that it was able to determine the contribution of MFI indicators on increased value in agriculture. This was critical to the study as the researcher was also able to analyze data elicited from the respondents that would contribute information on best practices while equally addressing the objectives of the study.

\subsection{Sample size determination}

The appropriate sample size is dependent on several factors which include the purpose of the study, availability of time and resources, heterogeneity of the population, the required confidence level and sampling error (Kasomo, 
2007). Samples were chosen using stratified sampling to ensure each county is proportionally represented. For primary data Krejcie and Morgan formular was used
$\mathrm{S}=$
$\mathrm{X}^{2} \mathrm{NP}(1-\mathrm{P})$

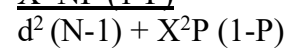

Where

$\mathrm{S}$ is the desired sample size

$\mathrm{X}^{2}$ is the table value of chi-square for one degree of freedom at desired confidence level which is $1.96 \mathrm{X} 1.96=$ 3.841

$\mathrm{N}$ is the population size (6134)

$\mathrm{P}$ is the population proportion assumed to be 0.5 since this will provide maximum sample size and $\mathrm{d}$ is the degree of accuracy expressed as a proportion 0.05

$\mathrm{S}=\frac{3.8416 \times 6134 \times 0.5(1-0.5)}{0.05^{2}(6134-1)+3.8416 \times 0.5(1-0.5)}=361.57$ which is 362 Respondents.

\subsection{Data Analysis Techniques}

Data analysis is a process of inspecting, cleaning, transforming, and modelling data with the goal of highlighting useful information, suggesting conclusions, and supporting decision making. The data collected in this study was firstly grouped, tabulated and classified. Secondly, the data was presented using frequency distribution tables, charts, and graphs. The data was edited by examining the collected raw data to detect errors and omissions and correct them. This included a careful scrutiny of the completed questionnaires or observation and or interview schedules the data was then be coded by assigning numerical to answers so that responses can be put into a limited number of categories or classes. The data analysis was done per the objectives.

\subsection{Model Specification}

The hypotheses were structured to ascertain the extent to which microfinance facilities can enhance the expansion capacity of small business in the study. This was expressed as:

$\mathrm{H}_{01}$ : There is no significant relationship between the MFI outreach on the realization of increased value in agriculture.

$\mathrm{H}_{01}$ was modelled as:

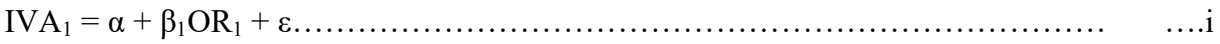

$\mathrm{H}_{02}$ : There is no significant role of portfolio quality of MFI on the realization of increased value in agriculture

$\mathrm{IVA}_{2}=\alpha+\beta_{2} \mathrm{PQ}_{1}+\varepsilon$ ....ii

$\mathrm{H}_{03}$ : There is no significant contribution of efficiency of MFI operations on the realization of increased value in agriculture

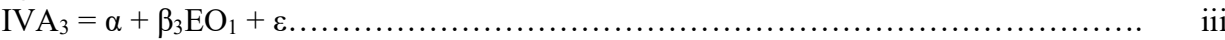

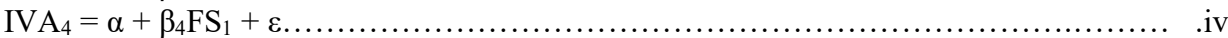

$\mathrm{H}_{04}$ : The joint contribution of microfinance institution indicators on the realization of increased value in agriculture is greater and different than the individual influence of each of the variables.

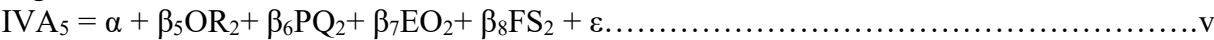

$\mathrm{H}_{56}$ : Land use policies have no significant intervening influence on the contribution of microfinance indicators on realization of increased value in agriculture.

$\mathrm{IVA}_{6}=\alpha+\beta_{9} \mathrm{OR}_{3}+\beta_{10} \mathrm{PQ}_{3}+\beta_{11} \mathrm{EO}_{3}+\beta_{12} \mathrm{FS}_{3}+\beta_{13} \mathrm{LUP}_{1}+\varepsilon \ldots \ldots \ldots \ldots \ldots \ldots \ldots \ldots \ldots \ldots \ldots \ldots \ldots \ldots \ldots \ldots \ldots$

$\mathrm{H}_{07}$ : political environment has no significant intervening influence on the contribution of microfinance institution indicators on realization of increased value in agriculture.

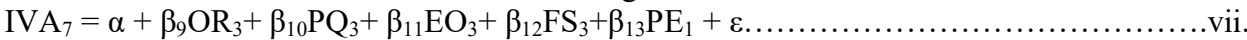

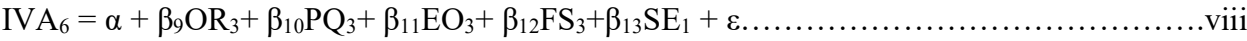

Where:

IVA $=$ Increased value in agriculture

$\alpha=$ regression constant derived from the y-intercept,

$\beta_{1}$ to $\beta_{13}=$ regression coefficients,

$\mathrm{OR}=\mathrm{MFI}$ outreach,

$\mathrm{PQ}=$ portfolio quality of MFI,

$\mathrm{EO}=$ Efficiency of MFI,

LIP $=$ Land Use Policies

$\mathrm{PE}=$ Political environment

$\mathrm{SE}=$ Socio-economic factors,

$\varepsilon=$ error term. 


\subsection{FINDINGS}

\subsection{Correlation Analysis}

4.2 Correlation Analysis between Independent Variables and Increased Value Chain

The correlation analysis of the independent and dependent variables was conducted and correlation coefficients obtained. The correlation analysis aided in assessment of the influence of all study variables on increased value chain in agriculture. The analysis was based on the objectives of the study. An analysis was thus carried out to assess the existence of a significant relationship between each MFI indicators and increased value in agriculture. The results are presented in Table 1.

Table1: Correlation Analysis between Independent Variables and Increased Value Chain

\begin{tabular}{|c|c|c|c|c|}
\hline & & Outreach & P. Quality & Efficiency \\
\hline \multirow{3}{*}{ MFI Outreach } & Pearson Correlation & 1 & & \\
\hline & Sig. (2-tailed) & & & \\
\hline & $\mathrm{N}$ & 312 & & \\
\hline \multirow{3}{*}{ Portfolio Quality } & Pearson Correlation & $.559^{* *}$ & 1 & \\
\hline & Sig. (2-tailed) & .000 & & \\
\hline & $\mathrm{N}$ & 312 & 312 & \\
\hline \multirow{3}{*}{ Efficiency } & Pearson Correlation & $.328^{* *}$ & $.565^{* *}$ & 1 \\
\hline & Sig. (2-tailed) & .000 & .000 & \\
\hline & $\mathrm{N}$ & 312 & 312 & 312 \\
\hline
\end{tabular}

**. Correlation is significant at the 0.01 level (2-tailed).

The results indicated that all independent variables had significant relationship with dependent variable (increased value chain in agriculture). The relationship between MFI outreach and increased value in agriculture was found to be strong and positive $(\mathrm{r}=0.669, \mathrm{p}=0.000)$. The relationship between portfolio quality and increased value in agriculture was strong $(\mathrm{r}=0.649, \mathrm{p}=0.000)$. Both efficiency was also found to have moderate positive relationships with increased value chain in agriculture at $(\mathrm{r}=0.531, \mathrm{p}=000)$

\subsection{Correlation Analysis between Moderating Variables and Increased Value}

An analysis was carried out to assess the existence of a significant relationship between each moderating variable and increased value in agriculture. The results are presented in Table 2.

Table 5: Correlation Analysis between Moderating Variables and Increased Value

\begin{tabular}{|c|c|c|c|c|}
\hline & & SEF & LUP & $\mathbf{P E}$ \\
\hline \multirow{3}{*}{$\mathbf{S E F}=$ Socio-economic Factors } & Pearson Correlation & 1 & $.588^{* *}$ & .000 \\
\hline & Sig. (2-tailed) & & .000 & .993 \\
\hline & $\mathrm{N}$ & 312 & 312 & 312 \\
\hline \multirow{3}{*}{$\mathbf{L U P}=$ Land Use Policies } & Pearson Correlation & $.588^{* *}$ & 1 & -.008 \\
\hline & Sig. (2-tailed) & .000 & & .887 \\
\hline & $\mathrm{N}$ & 312 & 312 & 312 \\
\hline \multirow{3}{*}{$\mathbf{P E}=$ Political Environment } & Pearson Correlation & .000 & -.008 & 1 \\
\hline & Sig. (2-tailed) & .993 & .887 & \\
\hline & $\mathrm{N}$ & 312 & 312 & 312 \\
\hline \multirow{3}{*}{ Increased Value in Agriculture } & Pearson Correlation & $.673^{* *}$ & $.425^{* *}$ & $-.127^{*}$ \\
\hline & Sig. (2-tailed) & .000 & .000 & .025 \\
\hline & $\mathrm{N}$ & 312 & 312 & 312 \\
\hline
\end{tabular}

**. Correlation is significant at the 0.01 level (2-tailed).

*. Correlation is significant at the 0.05 level (2-tailed).

The results indicated that all moderating variables had significant relationship with dependent variable (increased value chain in agriculture). The relationship between socio-economic factors and increased value in agriculture was found to be strong and positive $(\mathrm{r}=0.673, \mathrm{p}=0.000)$. The relationship between land use policies and increased value in agriculture was moderate $(\mathrm{r}=0.425, \mathrm{p}=0.000)$. However, there weak negative relationships with increased value in agriculture and political environment, $(r=0.127, p=025)$. 
4.4 Simple Linear Regression between Indicators and Increased Value in Agriculture

Regression analysis was conducted between individual MFI indicators and increased value chain. The coefficient of determination, $\mathrm{R}^{2}$ was relied on to overcome the problem of determining causality as it indicates the amount of variability in one variable that is explained by the others. The null hypotheses were tested using the $\mathrm{B}$ coefficient at $5 \%$ significant level. The criteria was $\mathrm{B} \neq 0$ and $\mathrm{P}<0.05$.

\subsection{Microfinance Outreach and Increased value in Agriculture}

A simple linear regression was carried to assess the influence of MFI outreach on the realization of increased value in agriculture for increased value in agriculture and thereby test the first research hypothesis of the study which posits: $\mathbf{H}_{01}$ : There is no significant relationship between the MFI outreach and the realization of increased value in agriculture for increased value in agriculture. This entails composite variable of MFI outreach index which was mean obtained from six metrics that was used to measure MFI outreach in this study. Similarly, the composite value of increased value chain was obtained by getting mean of five metrics that was used to measure increased value in agriculture. The results are presented in Table 3.

Table 6: Regression Analysis of Microfinance Outreach

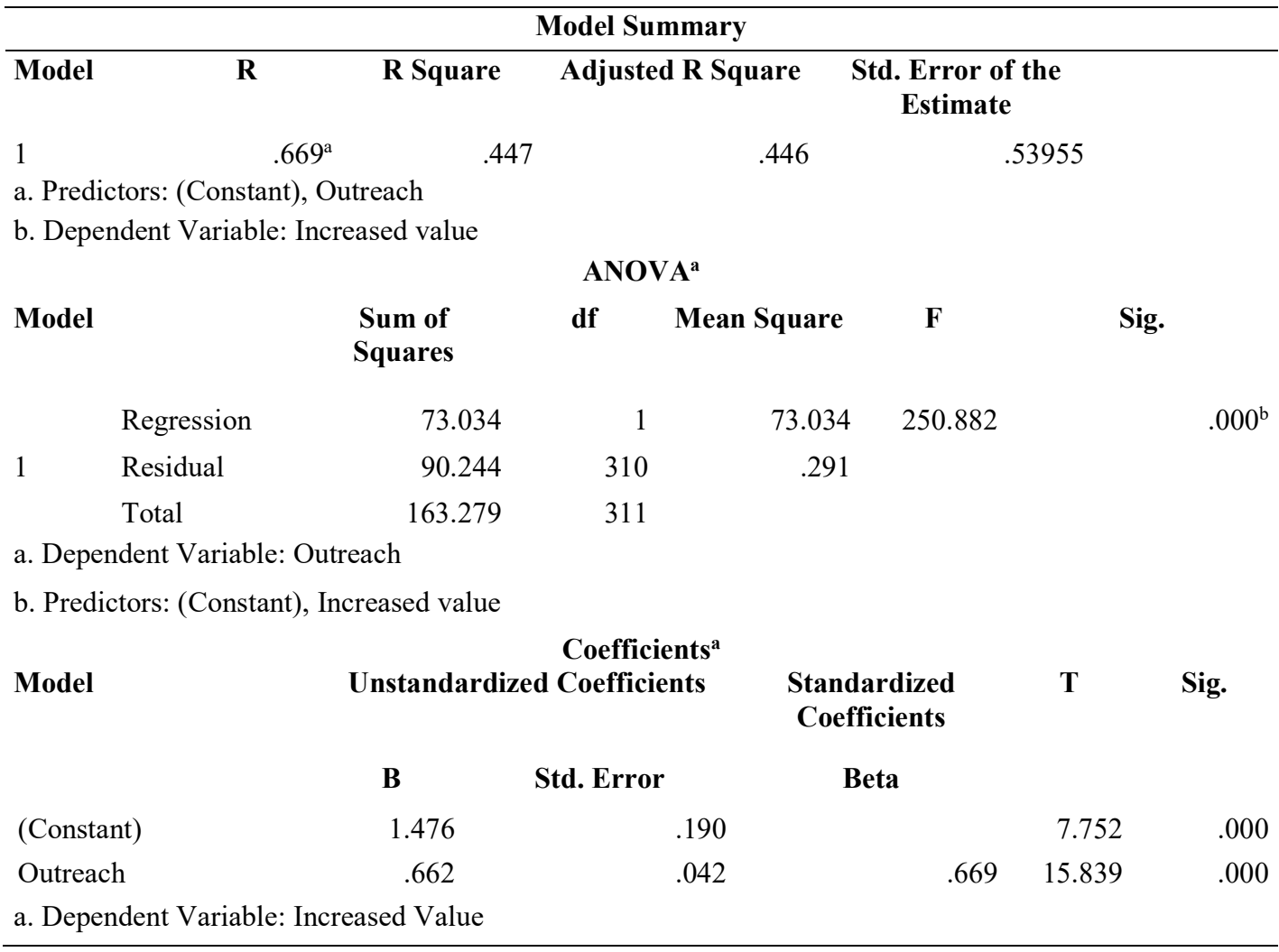

The proportion of variance in Increased value in agriculture explained by the independent variable (MFI Outreach) is $44.7 \%$ or $\mathrm{R}^{2}=0.447$. From the findings, the $\mathrm{F}$ ratio is greater than 1 , as indicated by a value of 250.882 , which means that improvement due to fitting the model is much greater than the model inaccuracies $(\mathrm{F}(1,311)=250.882$, $\mathrm{P}=0.000)$.. This implies that MFI Outreach is useful predictor of increased value in agriculture. From the findings presented in Table above, MFI Outreach carried positive significant predictive power $(B=0.662, p=.000)$ implying that a unit change in MFI Outreach level would result to significant change in agriculture value by 0.662 in the same direction. Therefore, the linear regression results indicated that there was a statistically significant positive relationship between MFI Outreach and Increased value in agriculture. The study developed analytical model for predicting increased value from MFI Outreach is stated in the form of:

Increased value $=1.476+0.662 \mathrm{MFI}$ Outreach 
4.6 Microfinance Portfolio Quality and Increased value in Agriculture

A simple linear regression was conducted to investigate the role of portfolio quality of MFI on the realization of increased value in agriculture for increased value in agriculture. The objective sought to test the second research hypothesis of the study which posits: Ho2: There is no significant role of portfolio quality of MFI on the realization of increased value in agriculture. This entails composite variable of MFI portfolio quality index which was mean obtained from six metrics that was used to measure MFI portfolio quality in this study. Similarly, the composite value of increased value chain was obtained by getting mean of five metrics that was used to measure increased value in agriculture. The results are presented in Table 4.

Table 7: Regression Analysis of Microfinance Portfolio Quality

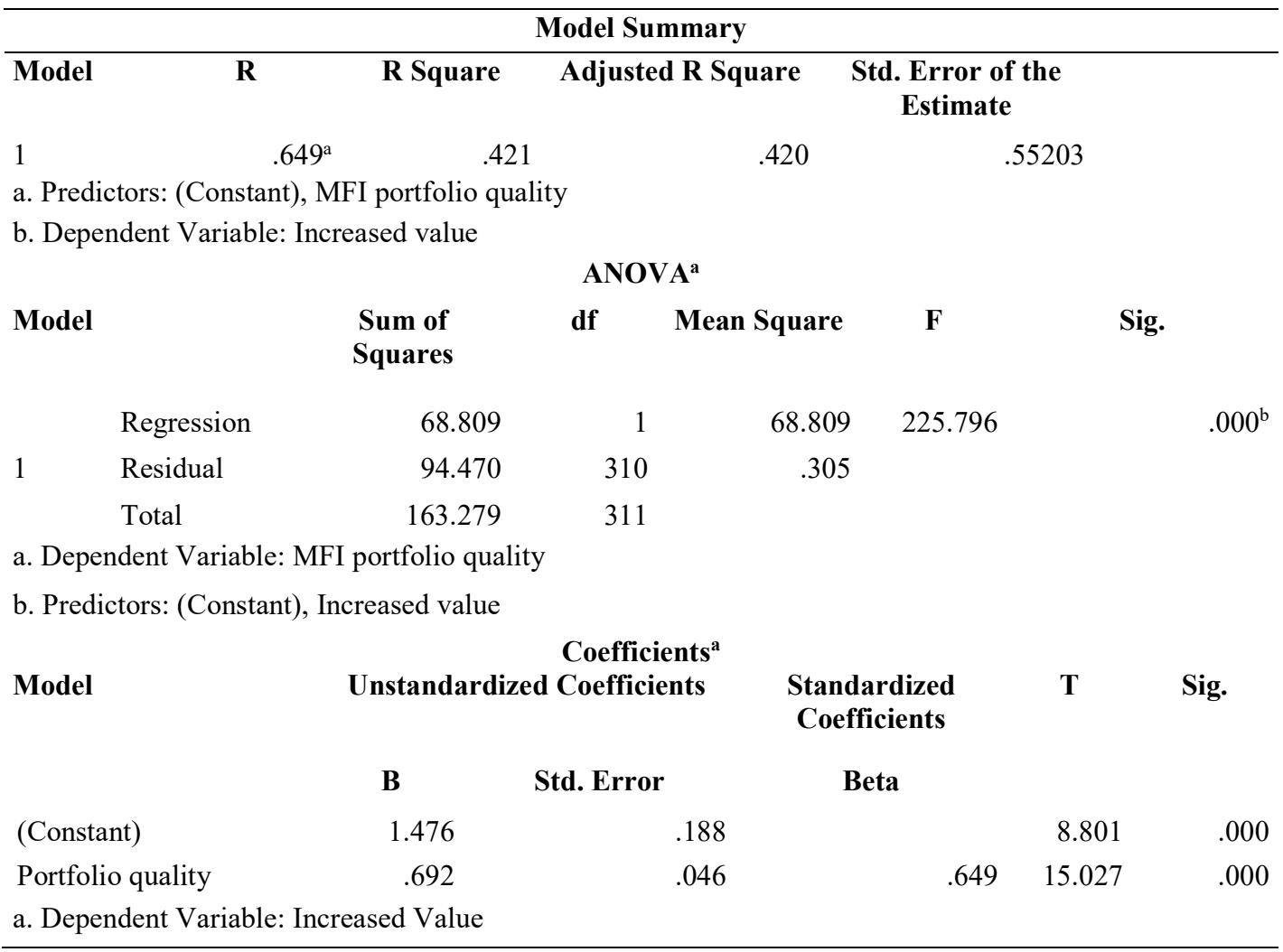

\section{Source: Field Data (2018)}

The percentage of variance in agricultural value accounted for by MFI portfolio quality is $44.7 \%$ or $\mathrm{R}^{2}=0.44 .7$. The $\mathrm{F}$ ratio is greater than 1 , as indicated by a value of 225.796 , which means that improvement due to fitting the model is much greater than the model inaccuracies $(\mathrm{F}(1,311)=225.796, \mathrm{P}=0.000)$.. This implies that MFI portfolio quality is useful predictor of increased value in agriculture. From the findings presented in Table above, MFI portfolio quality carried positive significant predictive power $(B=0.692, p=.000)$ implying that a unit change in MFI portfolio quality level would result to significant change in agriculture value by 0.692 in the same direction. Therefore, the linear regression results indicated that there was a statistically significant positive relationship between MFI portfolio quality and increased value in agriculture. The study developed analytical model for predicting increased value from MFI portfolio quality is stated in the form of:

Increased value $=1.476+0.692 \mathrm{MFI}$ portfolio quality

4.7 Microfinance Efficiency and Increased value in Agriculture

A simple linear regression was carried out to assess the efficiency of MFI operations on the realization of increased value in agriculture. The objective sought to test the third research hypothesis of the study which posits: $\mathbf{H}_{03}$ : There is no significant contribution of efficiency of MFI operations on the realization of increased value in agriculture. This entails composite variable of MFI efficiency index which was mean obtained from five metrics that was used to measure MFI efficiency in this study. Similarly, the composite value of increased value chain was obtained by 
getting mean of five metrics that was used to measure increased value in agriculture. The results are presented in Table 5 .

Table 8: Regression Analysis of Microfinance Efficiency

\begin{tabular}{|c|c|c|c|c|}
\hline \multicolumn{5}{|c|}{ Model Summary } \\
\hline Model & $\mathbf{R}$ & R Square & Adjusted R Square & $\begin{array}{l}\text { Std. Error of the } \\
\text { Estimate }\end{array}$ \\
\hline
\end{tabular}

1
a. Predictors: (Constant), MFI efficiency
b. Dependent Variable: Increased value

\section{ANOVA ${ }^{\mathrm{a}}$}

\begin{tabular}{|c|c|c|c|c|c|c|c|}
\hline \multirow[t]{2}{*}{ Model } & & $\begin{array}{c}\text { Sum of } \\
\text { Squares }\end{array}$ & Mean & Square & $\mathbf{F}$ & \multicolumn{2}{|c|}{ Sig. } \\
\hline & Regression & 45.979 & 1 & 45.979 & \multicolumn{2}{|l|}{121.515} & $.000^{\mathrm{b}}$ \\
\hline \multirow[t]{2}{*}{1} & Residual & 117.299 & 310 & .378 & & & \\
\hline & Total & 163.279 & 311 & & & & \\
\hline \multicolumn{8}{|c|}{ a. Dependent Variable: MFI efficiency } \\
\hline \multicolumn{8}{|c|}{ b. Predictors: (Constant), Increased value } \\
\hline \multirow{2}{*}{\multicolumn{2}{|c|}{ Model }} & \multicolumn{4}{|c|}{$\begin{array}{l}\text { Coefficients }^{\mathrm{a}} \\
\text { Unstandardized Coefficients }\end{array}$} & \multirow[t]{2}{*}{$\mathbf{T}$} & \multirow[t]{2}{*}{ Sig. } \\
\hline & & B & Std. Error & $\mathbf{B}$ & & & \\
\hline \multicolumn{2}{|c|}{ (Constant) } & 2.083 & .218 & & & 9.566 & .000 \\
\hline \multicolumn{2}{|c|}{ Efficiency } & .608 & .055 & & .531 & 11.023 & .000 \\
\hline
\end{tabular}

The results revealed a coefficient of determination $\left(\mathrm{r}^{2}\right)$ of 0.282 . Meaning MFI efficiency can explain up to 28.2 $\%$ of the variance in increased value chain of agriculture in Kenya. The F test gave a value of $(1,311)=121.515$, $\mathrm{P}<0.01$, which supports the goodness of fit of the model in explaining the variation in the dependent variable. It also means that MFI efficiency is a useful predictor of increased value in agricultural production in Kenya. The Unstandardized regression coefficient $(\beta)$ value of MFI efficiency was 0.608 and significance level of $p=.000$. This indicated that a unit change in MFI efficiency would result to change in increased value in agriculture by 0.608 significantly. The regression equation to estimate increased value in agriculture in Kenya as a result of MFI efficiency was hence stated as:

Increased value $=2.083+0.608 \mathrm{MFI}$ efficiency

\subsection{Multiple Linear Regression between MFI Indicators and Increased Value in Agriculture}

The purpose of the study was to conduct an empirical study on micro finance institutions indicators on contribution to the increased value in agriculture. This was achieved by carrying out standard multiple regression with the first model consisting of each of the MFI indicators. The study was interested in knowing the effect of each of the indicator on increased value in agriculture when all these constructs were entered as a block on the model. The results of multiple linear regression analysis were presented in Table 26 which contained ANOVA (goodness of fit; F Ratio, Sig Value) and model summary (R, R2, Adj R ${ }^{2}$ ) results while Table 5 contained regression coefficient (Unstandardized \& standardized), t-value and Sig. value results.

The study sought to determine the overall percentage change in the increased value in agriculture that was explained by all MFI indicators by use of $\mathrm{R}^{2}$. The results in Table 6 present $\mathrm{R}, \mathrm{R} 2, \mathrm{Adj} \mathrm{R}^{2}$, F ratio and Sig. value. 
Table6: Model Summary and ANOVA

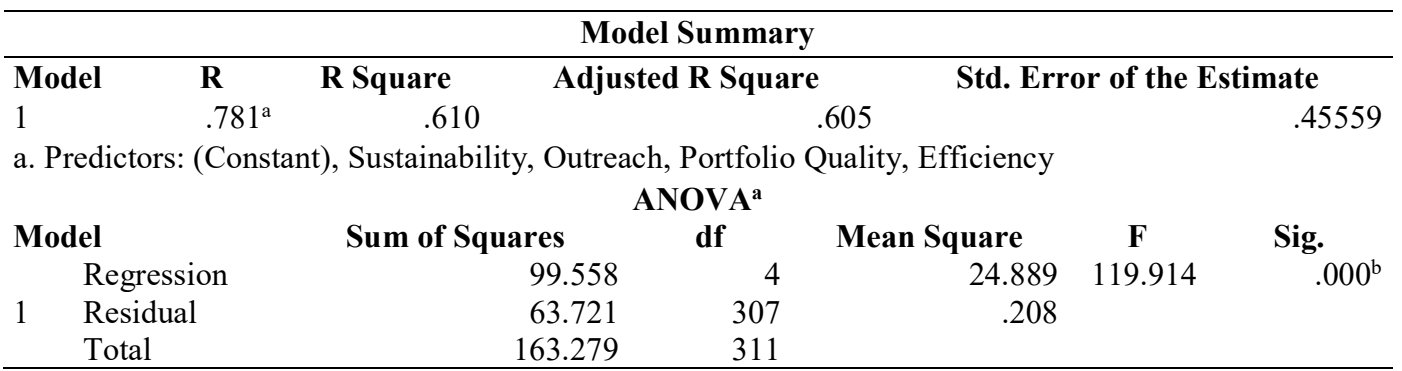

a. Dependent Variable: Increased value in agriculture

b. Predictors: (Constant), Sustainability, Outreach, Portfolio Quality, Efficiency

The results from the model summary in Table 27 give us information on the overall summary of the model. Looking at the R square column, we can deduce that all the MFI indicators account for $61.0 \%$ significant variance in increased value in agriculture $(\mathrm{R}$ square $=.610, \mathrm{P}=0.000)$ implying that $39 \%$ of the variance in increased value in agriculture is accounted for by other variables not captured in this model. From the findings, also adjusted $\mathrm{R}$ square value is obtained, which is a corrected $\mathrm{R}$ square value to provide a useful estimate of true study population. The difference between $\mathrm{R}^{2}$ and adjusted $\mathrm{R}^{2}$ is obtained by subtracting the later from the former $(.610-.605=0.005)$ a value when multiplied by $100 \%$ results in 0.5 percent. This reduction implies that should the model originated from the entire population instead of a sample, it would explain about $0.5 \%$ less variation in the study outcome. In order to assess the significance of the model, simply whether the study model is a better significant predictor of the increased value in agriculture rather than using mean score which is considered as a guess, the study resorted to $\mathrm{F}$ Ratio. The $\mathrm{F}$ value from study findings indicates the proportion of the improvement in predicting the results from fitting the model relative to the inaccuracy or errors that still prevails in the study model. From the findings, the $\mathrm{F}$ value is more than one, as indicated by a value of 119.914, which means that enhancement as a result of model fitting is much larger than the model errors/inaccuracies that were not used in the model $(\mathrm{F}(4,311)=$ $119.914, \mathrm{P}=0.000)$. The large $\mathrm{F}$ value is very unlikely to exist by chance $(99.0 \%)$, thus implying that the final study model has significant improvement in it is prediction ability of increased value in agriculture in Kenya.

The presented in Table 28 shows unstandardized coefficients, standardized coefficients, $\mathrm{t}$ statistic and significant values. The study has an option of either using Unstandardized Coefficients or Standardized Coefficients depending on the type of data. The study used unstandardized coefficient column because we want to compare determinants effect across same measures (Likert Scale 1 through 5). However, if the measure were different, then standardized coefficients which are based on standard deviation would be appropriate.

Table7: Coefficients of MFI Indicators

\begin{tabular}{|c|c|c|c|c|c|}
\hline \multirow[t]{2}{*}{ Model } & \multicolumn{2}{|c|}{ Unstandardized Coefficients } & \multirow{2}{*}{$\begin{array}{c}\text { Standardized } \\
\text { Coefficients } \\
\text { Beta } \\
\end{array}$} & \multirow[t]{2}{*}{$\mathbf{T}$} & \multirow[t]{2}{*}{ Sig. } \\
\hline & B & Std. Error & & & \\
\hline (Constant) & .382 & .201 & & 1.904 & .058 \\
\hline Outreach & .395 & .044 & .399 & 8.921 & .000 \\
\hline Portfolio Quality & .277 & .053 & .260 & 5.271 & .000 \\
\hline Efficiency & .167 & .057 & .146 & 2.918 & .004 \\
\hline
\end{tabular}

a. Dependent Variable: Increased value in agriculture

From the findings presented in Table 7, it looked at the model results and scan down through the unstandardized coefficients B column. All for determinants had significant effect on the increased value in agriculture. If the determinants are held at zero or it is absent, the increased value in agriculture in Kenya would be $0.382, p=0.058$ though positive but insignificant. It was revealed that MFI outreach had largest unique significant contribution to the model with $\mathrm{B}=.395, \mathrm{p}=.000$ suggesting that controlling of other variables in the model, a unit change in MFI outreach would result to significant change in increased value in agriculture by 0.395 in the same direction as a result of higher MFI outreach in the bank. Therefore, the first hypothesis was rejected since $\beta_{1} \neq 0$ and $\mathrm{P}$ value $<0.05$.

The second largest beta coefficient was 0.277 , which is coefficient value for MFI portfolio. This values are significant $(\mathrm{B}=.277, \mathrm{p}=.000)$ and also positive. This means that MFI portfolio has the strongest unique contribution 
to explaining the increased value in agriculture in Kenya, when the variance explained by all other variables in the model is controlled. This implies that a unit change in MFI portfolio would result to change in increased value in agriculture by 0.277 in the same direction. Therefore, the second hypothesis was rejected since $\beta_{2} \neq 0$ and $\mathrm{P}$ value $<0.05$.

Another variable that also had a unique significant contribution to the model was the value for MFI efficiency $(\mathrm{B}=.167, \mathrm{p}=.004)$, lower than MFI portfolio. When other variables in the model are controlled, a unit change in MFI efficiency would result to significant change in increased value in agriculture by 0.167 in the same direction. A regression of the four predictor variables against increased value in agriculture established the multiple linear regression model as indicated in Table 7:

Increased value in agriculture $=0.382+0.395 \mathrm{X}_{1}+0.277 \mathrm{X}_{2}+0.167 \mathrm{X}_{3}+0.133 \mathrm{X}_{4}$

\subsection{SUMMARY, CONCLUSION AND RECOMMENDATIONS}

\subsection{Summary of findings}

The purpose of the study was to conduct an empirical study on micro finance indicators of contribution to the increased value in agriculture. Four objectives were developed to guide the study. Independent variable was MFI indicators which included outreach, portfolio quality and efficiency. The dependent variable was the realization of increased value in agriculture. Land policy and regulation, socio-economic factors and political environment were used as intervening variable. Data for the study was collected using questionnaires, interview and FGDs. A review of related literature was done in order to establish the basis of the study. A sample size of 384 MFI clients' respondents and 75 MFI officials' respondents was used in the study. MFI official questionnaires had $88.0 \%$ response rate while MFI clients questionnaire had $79.69 \%$ response rate. To achieve these objectives, seven hypotheses were formulated and tested using correlation analysis and simple and multiple regressions. The results supported all the seven hypotheses of the study as discussed in the following sections.

From the purpose of the study, the findings revealed that most of the clients of MFI registered positive growth of their business which included agribusiness, trading and business. There was notable easy access to fund from MFI due to outreach and efficiency, business expansion and creation of employment opportunities for others in the society. Some of the client used the proceeding from loan invested to facilitate family education, food security, improve housing and payment of medical bills. The MFI indicators explained up to $86.3 \%$ of variance in the realization of increased value in agriculture. To determine the role of intervening variables, hierarchical regression analysis was used where by their effect were control. Land policy and socio-economic factors contributed $0.1 \%$ above MFI indicators in the realization of increased value in agriculture while political environment did not anything above MFI indicators in the realization of increased value in agriculture.

\subsection{Assess the influence of MFI outreach on the realization of increased value in agriculture}

The first objective of the study was to assess the influence of MFI outreach on the realization of increased value in agriculture. The results indicated that MFI outreach had a statistically significant influence on the realization of increased value in agriculture in Kenya. The hypothesis that there is no significant relationship between the MFI outreach on the realization of increased value in agriculture was rejected by the study. Most of the MFI had increased their customer through MFI breadth of outreach and special loans targeting marginal groups through depth of outreach. Secondary data from MFI revealed an increase in breadth of outreach as well as increase in depth of outreach between 2010 and 2013. The outstanding loan also revealed an increase in trend of a relationship between average outstanding loan and depth of MFI outreach. The intervening variables jointly had significant influence on the relationship between outreach and realization of increased value in agriculture. Political environment had highest significant influence of the three variables on the relationship between MFI outreach and realization of increased value in agriculture.

\subsection{The role of portfolio quality of MFI on the realization of increased value in agriculture}

The second objective was to investigate the role of portfolio quality of MFI on the realization of increased value in agriculture. The results indicated that MFI portfolio quality had a statistically significant influence on the realization of increased value in agriculture in Kenya. The hypothesis that there is no significant role of portfolio quality of MFI on the realization of increased value in agriculture was rejected by the study.

The MFI had sound market risk, credit risk, operational risk and risk measurement which ensure acceptable quality of MFI loan portfolio. Secondary data revealed an increase in portfolio at risk over 30 days as well as increase in write off ratio. These two indicators have significant positive correlation. In the period between 2012 and 2013 , the portfolio yield of MFI reduced as the write off and PAR increased. However, provision expense ratio reduced. 
This implies that PAR has negative relationship with portfolio yield while positive relationship with write off and provision expense ratio.

PAR had positive relationship with outreach indicators while portfolio yield had negative relationship outreach indicators. There was also significant relationship amongst credit risk, market risk, operational risk and risk measurement. Socio -economic factors had least influence on the relationship between MFI portfolio quality and realization of increased value in agriculture.

\subsection{Assess the efficiency of MFI operations on the realization of increased value in agriculture}

The third objective was to assess the efficiency of MFI operations on the realization of increased value in agriculture. The results indicated that MFI efficiency had a statistically significant influence on the realization of increased value in agriculture in Kenya. The hypothesis that there is no significant contribution of efficiency of MFI operations on the realization of increased value in agriculture was rejected by the study. The cost needed to operate unit of portfolio was manageable and there was increase in loan officer productivity. The MFI were also found to use modern technology which enabled them to serve their client better.

Secondary data revealed a positive trend in loan officer productivity and credit officer ratio. Further, cost per borrower was in decreasing trend as well as operation expense ratio. The relationship between cost per loan and loan staff productivity was negative. The relationship between cost per loan and operating expense was positive while relationship between staff productivity and operating expense is negative. MFI efficiency had positive relationship with outreach through staff productivity and depth of outreach and negative relationship through staff productivity and breadth of outreach, depth and OER, cost per loan and outreach and average outstanding loan portfolio. On portfolio quality, credit officer ration had inverse relationship with PAR and write off ratio. Portfolio yield had positive relationship credit officer ratio. Operating expense ratio had inverse relationship with PAR while staff productivity had inverse relationship with write off ratio. On the intervening variable, land policy had lead influence while political environment had most influence on the relationship between MFI efficiency and realization of economic pillars vision 2030.

\subsection{Conclusion}

The study concluded that MFI outreach had significant positive influence on the realization of increased value in agriculture. This was achieved by MFI increasing the breadth and depth of outreach as well as involvement of training and education to their client. MFI portfolio quality had significant positive role on the realization of increased value in agriculture. The MFIs had market risk, credit risk, operational risk and risk measurement which were used to manage portfolio quality. The portfolio at risk for over 30 days and write off ratio depicted decreasing trends which implies that most of the MFI were managing their portfolio quality so that credit funds are available for clients. However, the political environment affected the portfolio quality which led to high portfolio quality.

The study concluded that efficiency of MFI operations had significant positive influence on the realization of increased value in agriculture. The MFI realize efficiency through decrease in operating expense ratio while increase in staff productivity and credit officer ratio. The use of modern technology increases the ability of MFIs to reach existing and new client thus contributing to realization of increased value in agriculture. The efficiency of MFIs through use of technology enables the management to monitor customer account especially on loan repayment progress. Overall, MFI indicators have significant contribution to the realization of increased value in agriculture through its outreach, portfolio quality, efficiency and financial sustainability. The contribution is intercalated between the indicators. MFI outreach and efficiency is the social obligation of MFI to alleviate poverty and reach out to those excluded from formal financial services. The financial obligation of MFI is financial sustainability and portfolio quality. For MFI to reach out to the poor (Outreach), they need to be efficient (efficiency) in the use of their resources (portfolio quality) so that they can achieve sustainability (financial sustainability).

\section{REFERENCES}

Abdelkader, B., Jemaa, B., \& Mekki, M. (2012). Microfinance Institutions' Efficiency in the MENA region: a Bootstrap-DEA approach.

Abdelkader, B., Jemaa, B., \& Mekki, M. (2012). Microfinance Institutions' Efficiency in the MENA region: a Bootstrap-DEA approach. (Working Paper). Tunis. Retrieved from http://hdl.handle.net/10419/69525

Abdulaziz, M. (2009). Evaluating the Self-Sustainability of (MFIs) Using the Balanced Scorecard Approach MBA Thesis. Sana'a University 
Acharya, Y.P., \& Acharya, U. (2006). "Sustainability of MFI from Small Farmer's Perspective: A case study of rural Nepal", Institutional Review of Business Research Papers, Vol. 2, No. 2, pp. 117-126\

Adongo, J., \& Stork, C. (2005). "Factors Influencing the Financial Sustainability Of Selected Microfinance Institutions in Namibia”, NEPRU Research Report, No. 39

Adugna, S. (2014). Determinants of Microfinance Institutions Loan Portfolios Quality: Empirical Evidence from Ethiopia MSc thesis Addis Ababa University

AEMFI (2012).Organization Statement.Association of Ethiopian Microfinance Institutions Addis Ababa, Ethiopia.

Agarwal, P.K. and Sen, P.K. (2009). Disclosure and financial performance:A cross-sectional study of microfinance institutions of India. Business Vision, Vol.5.5.No. 2, 2009.

Agarwal, S. (2012). "Regulating Consumer Financial Products: Evidence from Credit Cards." Quarterly Journal of Economics 130 (1): 111-64.

Aghion, B. \& Morduch, J. (2005). Microfinance beyond group lending. Economics of Transition, 8, 401-420.

Aghion, B., \& Morduch, J. (2005).The Economics of Microfinance. London,

Ahmad, U. (2011). Efficiency Analysis of Micro-finance Institutions in Pakistan, Report No. 34215, MPRA.

Amanor, K. (2012). Assessing the Cost Efficiency of Microfinance Institutions in Ghana: An Application of Stochastic Frontier Approach. Master of Arts. Kwame Nkrumah University of Science and Technology

Arko, S.K. (2012). Determining the causes and impact of nonperforming loans on the operations of microfinance institutions: A case of Sinapi Aba Trust. An executive MBA thesis. Kwame Nkruma University and Technology, Accra, Ghana.

Arodi, J. (2013). The relationship between outreach and financial sustainability of microfinance institutions in Nairobi County. Master Thesis. University of Nairobi

Athanasoglou, P, Brissimis,S. and Matthaios, D. (2005). Bank specific, industry-specific and Macroeconomic determinants of bank Profitability. MPRA Paper No. 32026 posted 5. July 2011 14:01 UTC, Bank of Greece

Ayayi, A.G., \& Sene, M. (2010). "What Drives Microfinance Institution's Financial Sustainability." Journal of Developing Areas 44(1):303-324.

Balkenhol, B. (2007). Microfinance and public policy: Outreach, performance and efficiency.ILO.

Balsley, S. (1970). Banking on Social Change: Grameen Bank Lending to Women. International Journal of Politics, Culture and Society, Vol. 16, No. 3 , 369-385.

Bamlaku, A. (2006). Microfinancing and Poverty Reduction in Ethiopia. A Paper prepared under the Internship Program of IDRC, ESARO, Nairobi, 2006.

Bartlett, J. E., Kotrlik, J. W., \& Higgins, C. C. (2001). Organizational research: Determining appropriate sample size in survey research. Information Technology, Learning, and Performance Journal, 19(1), 43-50.

Bassem, S. B. (2008). Efficiency of Microfinance Institutions in the Mediterranean: An application of DEA. Transit Stud Rev $15,343-354$.

Baumann, T. (2005). Pro poor Microcredit in South Africa: Cost Efficiency and Productivity of South African pro-poor microfinance institutions. Journal of Microfinance, 7(1), 95-118.

Bayeh, K. A. (2012). Financial Sustainability of Microfinance Institutions (MFIs) in Ethiopia. Journal of Business and Management , 4 (15).

Befekadu, K. (2007). Outreach and Financial Performance Analysis of Microfinance Institutions in Ethiopia. African Economic Conference United Nations Conference Center (UNCC), Addis Ababa.

Begg, D., Fischer, S. \& Dornbusch, R. (2005). Economics. Eighth Edition. McGraw Hill

Bell, J. (1993). How to complete your Research project successfully. New Delhi.

Bereket, Z. \& Lalitha, R. (2009). Is There a Tradeoff between Outreach and Sustainability of Micro finance institutions? Evidence from Indian Microfinance Institutions (MFIs). European Journal of Business and Management.।

Bi, Z., \& Pandey, S. (2011). Comparison of Performance of Microfinance with Commercial Banks. Australian Journal of Business and Management Research, 1(6), 110-120.

Bichanga, W., \& Aseyo, L. (2013). Causes of Loan Default within Micro Finance Institutions in Kenya. Interdisciplinary Journal of Contemporary Research in Business Vol 4, No 12

Brau, C., \& Woller, G. (2004). Microfinance: A Comprehensive Review of the Existing Literature. Journal of Entrepreneurial Finance and Business Ventures, Vol. 9, No. 1; pp. 1-26. 
Brau, J. C. and Woller, G. M. (2004) „Microfinance: A Comprehensive Review of the Existing Literature." Journal of Entrepreneurial Finance and Business Ventures, 9(1), 1-26.

Brau, J. C., \& Woller, G. M. (2004). Microfinance: A comprehensive review of the existing literature. Journal of Entrepreneurial Finance and Business Ventures, 9(1), 1-26.

Bridges, S., \& Disney, R. (2004). 'Use of credit and arrears on debt among low income families in the United Kingdom', Fiscal Studies, 25 (March) 1-25.

CGAP (2003). Microfinance consensus guidelines: Guiding principles on regulation and supervision of Microfince. Washington, DC.

CGAP (2003). Microfinance consensus guidelines: Guiding principles on regulation and supervision of Microfince. Washington, DC.

CGAP (2004). Market opportunities for Microfinance Investment Funds. Kfw Financial sector development. Sympsium. Microfinance Investment Funds, Berlin, November.

CGAP (2006). Market opportunities for Microfinance Investment Funds. Kfw Financial sector development. Sympsium. Microfinance Investment Funds, Berlin , November.

CGAP. (2012). Financial analysis for microfinance institutions. Participant Course Material. Consultative Group to Assist the Poor.

Chant \& Link Associate (2004) Access to consumer credit: the problem of financial exclusion in Australia and the current regulatory framework. Macquarie Law Journal, 5(2005), pp. 127-148.

Chemining'wa, T. (2013). The relationship between MFI outreach services and financial sustainability in Kenya. Master Thesis. University of Nairobi

Chong, F. (2010). Evaluating the Credit Management of Micro-Enterprises. Department of Banking and Finance. University of Technology. MARA, 2(7), 149-158.

Chu M (2008). "Microfinance: Mobilizing Markets to Fight Poverty, The Latin American Experience." A Paper presented at Building Broad-Based Economic Growth Seminar 47th Annual Meeting of Inter-American Development Bank. Belo Horizonte: Brazil. March.

Cochran, W. G. (1977). Sampling Techniques. 3rd ed. New York: John Wiley \& Sons.

Coleman, A., \& Osei, K. (2008). Outreach and profitability of microfinance institutions: the role of governance. Journal of Economic Studies, Vol. 35 Iss: 3 pp. 236 - 248.

Coleman, Brett E. (2006). Microfinance in Northeast Thailand: Who Benefits and How Much? World Development 34 (9), 1612-1638.

Cooper, D., and Schindler, P. (2003).Business Research Methods. Tata McGravo-Hill, New York. 12-16

Copestake, J., Dawson, P., Fanning, J., Mckay, A. \& Wright-Revolledo, K. (2007). Monitoring the diversity of the poverty outreach and impact of microfinance: a comparison of methods using data from Peru Development Policy Review Volume 23, Issue 6, 703-723.

Cromie, S. (1991). The problems experienced by young firms. International Small Business Journal, 9(3), 43-61.

Cull, R., Demirguc-Kunt, A. \& Morduch, J. (2006). Financial performance and outreach : a global analysis of leading microbanks. The World Bank. Available at: http://ideas.repec.org/p/wbk/wbrwps/3827.html [Accessed November 20, 2012].]

Demsetz, H. (1973). Industry Structure, Market Rivalry and Public Policy, Journal of Law and Economics, Vol.16, N.1, pp.19 .

Diagne, A., \& Zeller, M. (2001).Access to credit and its impact on welfare in Malawi. Research Report II6 International Food Policy Research Institute. Washington DC

Dissanayake, D.M.N.S.W and Anuranga, B.K.D.H.,(2012), The determinants of return on equity: evidences form microfinance institutions in Srilanka, SSRN working paper.

Dunford, C. (2003). The Holy grail of microfinance: helping the poor and sustainable Microfinance evolution, achievements and challenges. ITDG, London.

Elton, E., \& Gruber, M.J. (1995). Modern Portfolio Theory and Investment Analysis, 5th ed. Wiley, New York.

Essentials (2009). “Microfinance” A Synthesis of Lessons Learned. Evaluation office No.3.

Evans, J.' \& Winston, E. (2008). Loan Delinquency among Small Business Owners in Ghana: The Importance of Gender to the Lending Process. International Journal of Entrepreneurship and Small Business, 5(3/4), 318-336. 
Frankfort-Nachmias, C., \& Nachmias, D. (1992): Research Methods in the Social Sciences, 4th edition, London, Melbourne. (5th edition 1996).

Freixas, X., \& Rochet, J. (2008). Macroeconomics of Banking, Second edition, MIT Press

Gall, M. D., Gall, J. P., \& Borg, W. R. (2007). Educational Research, 8th Edition. Boston: Pearson Education, Inc.

Ganka, D. (2010). Financial sustainability of rural microfinance institutions in Tanzania. PHD thesis, University of Greenwich, Australia.

Ganka, D. (2010). Financial sustainability of rural microfinance institutions in Tanzania. PHD thesis, University of Greenwich, Australia.

Garson M. (2012).Type I Error Rate and Power of Three Normality Tests Pakista Journal of Information and Technology.

Gastwirth A., Azna F., Ibrahim K. \& Jemain A. A. (2009) On the Comparison of Several Goodness of Fit tests under Simple Random Sampling and Ranked Set Sampling World Academy of Science and Engineering Technology.

Giday, G., \& Chawla, S. (2015). Outreach and Sustainability of Microfinance Institutions of Ethiopia: A Case Study on Specialized Financial and Promotional Institution (SFPI). International Journal of Management and Commerce Innovations ISSN 2348-7585. Vol. 3, Issue 2, pp: (1024-1046)

GoK (2012). Second medium term plan, 2013 - 2017: transforming Kenya: pathway to devolution, socio-economic development, equity and national unity. Government Printer. Nairobi

Gonzalez, A. (2008). "Efficiency Drivers of Microfinance Institutions (MFIs): The Case of Operating Expenses." MicroBanking Bulletin Highlights, Autumn.

Hair, JF, Bush, RP \& Ortinau, DJ, (2003). Marketing research: Within a changing information environment, 2nd edn. McGrawHill/ Irwin, New York

Haq, M., Skully, M., \& Pathan, S. (2010). Efficiency of microfinance institutions: a data envelopment analysis, Asia-Pacific Financial Markets, Vol. 17, No. 1, pp. 63-97.

Hardy, D., Holden, P., \& Prokopenko, V. (2003). "Microfinance institutions and public policy", Journal of Policy Reform, 6 , 2003, pp. 147-158.

Hartarska, V. (2005), "Government and performance of microfinance institutions in Central and Eastern Europe", World Development, vol. 33, pp. 1627-43.

Hassan, M. K., Sanchez, B., \& Ngene, G. (2012). Scales and technical efficiencies in Middle East and North African (MENA) micro financial institutions. International Journal of Islamic and Middle Eastern Finance and Management, 5(2), $157-$ 170 .

Hermes, N \& Lensink, R. (2011). Microfinance: Its Impact, Outreach, and Sustainability, World Development Vol. 39, No. 6, pp. $875-881$

Hermes, N. \& Lensink, R. (2007). The Empirics of Microfinance: What do we do now? The Economic journal, 117, pp-1-10

Hermes, N., Lensink, R., \& Meesters, A. (2011). Outreach and Efficiency of Microfinance Institutions, World Development Vol. 39, No. 6, pp. 938-948

Hollis, A and Sweetman, A. (2007). The role of local depositors in controlling expenses in small-scale financial intermediation: an empirical analysis. Economica, 74:713-735.

Honohan, P. (2004) .Financial Development, Growth and Poverty: How Close Are the Links?. World Bank Policy Research Working Paper 3203, February.

Hoque, M., Chisty, M., \& Halloway, R. (2011). Commercialization and changes in capital structure in microfinance institutions - An innovation or wrong turn? Managerial Finance Vol. 37 No. 5, pp. 414-425

Hossain, S., \& Khan, A. (2016). Financial Sustainability of Microfinance Institutions (MFIs) of Bangladesh. Developing Country Studies Vol.6, No.6

Hulme, D., \& Mosley, P. (1996). Finance Against Poverty. London: Routledge.

Iezza, P. (2010). Financial sustainability of microfinance. Copenhagen: Copenhagen Business School.

Iftekhar, A., Abul, B., Jamaliah, S., \& Mohd, F. (2014). BREADTH OF OUTREACH AND ACCOUNTABILITY OF MICROFINANCE INSTITUTIONS (MFIS) IN SOUTH ASIAN REGION The Global Journal of Finance and Economics, Vol. 11, No. 2, (2014) : 161-173

Islam, K., Bäckman, S., \& Sumelius, J. (2011). Technical, Economic and Allocative Efficiency of Microfinance Borrowers and Non-Borrowers: Evidence from Peasant Farming in Bangladesh. European Journal of Social Sciences, 18(3), 361377. 
Jansson.T. (2002). Performance Indicators for MFI's: Technical Guide. Micro Rate and Inter- Americal Development Bank, Washington, DC available at www.microrate.com

Kabedea, H., \& Berhanu, W. (2013). How Efficient are Ethiopian Microfinance Institutions in Extending Financial Services to the Poor? .A comparison with Commercial Banks. Journal of African Economies.22(1),112-135

Kassa, T.(2008). Microfinance as a Strategy for Poverty Reduction. A Research Paper A Comparative Analysis of ACSI and Wisdom Microfinance Institution in Ethiopia in partial fulfillment of the requirements for obtaining the degree of masters of arts in development studies specialization: Local and Regional Development (LRD)

Kaur, P. (2014). Outreach and Sustainability of Microfinance Institutions in India in Pre and Post Andhra Pradesh Microfinance Crisis in Context of South Asia. Global Journal of Finance and Management. Volume 6, Number 6 (2014), pp. 569574

Kavoo, A. (2013). The Effect of Outreach on the Growth of Microfinance Institutions in Nakuru County. Master Thesis. University of Nairobi

Kealey, D.J., \& Protheroe, D.R. (1996). The effectiveness of cross-cultural training for expatriates: An assessment of the literature on the issue. International Journal of Intercultural Relations, 20(2), 141-165.

Kelegama, S. (2011). Economic and Social Development in Sri-Lanka. Asian Development Bank Institute, 1 (3), 504-507.

Khandker, S. R. (2006). Microfinance and poverty evidence using panel data from Bangladesh. Policy Research Working Paper Series 2945, The World Bank.

Kidzuga, A. (2013). The Relationship between Financial Sustainability and Outreach Of Microfinance Institutions In Kenya Master Thesis. University of Nairobi

Kiiru, J. M. (2007). The impact of microfinance on rural poor households income and vulnerability to poverty: Case study of Makueni District, Kenya. MBA Thesis University of Nairobi.

Kimando, L. N., Kihoro, J. M., Njogu, G. W. (2012), Factors Influencing the Sustainability of Micro-Finance Institutions in Murang'a Municipality, International Journal of Business \& Commerce; Jun2012, p21

Kinde, B.A. (2012). Financial Sustainability of Microfinance Institutions (MFIs) in Ethiopia. European Journal of Business and Management, Vol. 4. No. 12, 2012.

Kioko, J. M. (2012), An investigation into factors influencing financial sustainability of micro finance institutions in Kenya, Unpublished MBA Project, Kenyatta University

Kipesha, E. F., \& Zhang, X. (2013). Sustainability, Profitability and Outreach Tradeoffs: Evidences from Microfinance Institutions in East Africa. 5 (8).

Kothari, C.R. (2004). Research Methodology Methods \& Techniques 2nd Edition. New Delhi, India. New Age International (P) Limited.

Lafourcade, A., Isern, J., Mwangi, P. and Brown, M. (2005).Overview of the outreach and financial performance of microfinance institutions in Africa. MIX, 2005.

Ledgerwood, J. (1999). An institutional and finance perspective. Microfinance handbook. The World Bank Publications, USA.

Leedy, P. D., \& Ormrod, J. E. (2005). Practical research: Planning and design (8th ed.). Upper Saddle River, NJ: Prentice Hall.

Letenah, E. (2009). Performance analysis of a sample microfinance institutions of Ethiopia: university Business School, Panjab University, Chandigarh, India, March 2009.

Lipsey, R., \& Chrystal, A. (2007). Economics. Eleventh Edition. Oxford Publishers

Littlefield, E. \& Rosenberg, R. (2004). Microfinance and the poor, Journal of Development Economics, 78(2)

LOGOTRI (2006). Building Sustainable Microfinance System: A Growth Catalyst for the Poor. Local Government Training and Research Institute, Society for Development Studies.

Magiri, A. (2014). Relationship between Outreach and Financial Performance of Deposit Taking Micro Finance Institutions in Kenya. Master Thesis. University of Nairobi

Malkawi, E., \& Atoom, R. (2011). Jordan Microfinance Institutions' Financial Viability to Achieve Microcredit Outreach, European Journal of Economics, Finance and Administrative Sciences ISSN 1450-2275 Issue 42, 2011

Mandelbrot, B. (2004). "New methods of statistical economics," revisited: Short versus long tails and Gaussian versus powerlaw distributions. Complexity, 14(3), 55-65.

Manos, R., \& Yaron, J. (2009). Key Issues in Assessing the Performance of Microfinance Institutions“ Canadian Journal of Development Studies, 29: 1, $101-122$ 


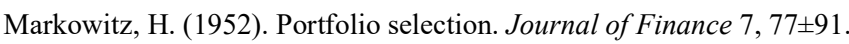

Martínez-González, A. (2008). Technical Efficiency Of Microfinance Institutions: Evidence From Mexico. The Ohio State University.

Matovu, D. (2006). Micro-finance and Poverty Alleviation Uganda. Africa and International Development Cooperation, 1-64.

Matveev, A.V. (2002). 'The advantages of employing quantative and qualitative methods in intercultural research: Practical implications from the study of the perceptions of intercultural communication competence by American and Russian managers', Bulletin of Russian Communication Association, Vol. 1, pp.59-67.

McIntosh, C., \& Wydick, B. (2005). Competition and microfinance, Journal of Development Economics 78, 271 - 298

Mersland R, Strøm R (2009). Performance and governance in microfinance institutions. J. Bank. Finance., 4: 662-669.

Meyer, J. (2002). Track record of financial institutions in assessing the poor in Asia. ADBresearch institute paper, No. 49, September 30, 2011.

Meyer, R. (2002). "Track Record of Financial Institutions in Assisting the Poor in Asia" ADB Institute Research Paper, No 49, December 2002.

MIX (2009), "Microfinance in Ethiopia", Microfinance Information Exchange (MIX) market, [Online] Available: http://www.mixmarket/mfi/country/Ethiopia ( October 2, 2011).

Mixmarket. (2013). Retrieved from http://www.mixmarket.org/mfi/grameen-bank

Mjomba, E. (2011). Microfinance and financial empowerment of women in Kenya: the case of Kenya Women Finance Trust. MBA Thesis University of Nairobi 